\title{
腎細胞癌に括ける核小体形成部位の検討
}

\author{
千葉大学医学部泌尿器科 (主任：島崎 淳教授) \\ 阿部 功一 正井 基之 井坂 茂夫 島崎 淳 \\ 千葉県がんセンター病理 \\ 松 㟢 理
}

\section{NUCLEOLAR ORGANIZER REGIONS IN RENAL CELL CARCINOMA}

\author{
Kouichi Abe, Motoyuki Masai, Shigeo Isaka and Jun Shimazaki \\ Department of Urology, School of Medicine, Chiba University \\ (Director: Prof. Jun Shimazaki) \\ Osamu Matsuzaki \\ Department of Pathology, Chiba Cancer Center
}

Argyrophilic Nucleolar Organizer Regions (AgNORs) were examined in 96 patients with renal cell carcinoma undergoing nephrectomy at Department of Urology, Chiba University Hospital during 1985-1990. Silver staining was performed with one-step method described by Ploton ${ }^{51}$, and average numbers of grains in a cell were obtained by counting 100 cells.

Numbers of AgNORs were increased along with up grading. When AgNORs were compared in various cell types, the number in pleomorphic and spindle types and that in Bellini duct carcinomas were more than that in common types. The number of AgNORs correlated with $\mathrm{pT}$ and $\mathrm{pV}$ factors, but no relationship was shown between the number and these factors when compared in the same grade. The tumor size correlated with the number of AgNORs. The number of AgNORs in the primary legion showed a reversed correlation with doubling times calculated from either primary, recurrent or metastatic legions examined in 22 cases. In all cases it tended that the number of AgNORs correlated with survival, however survival in G3 cases was not influenced due to worse prognosis.

It was concluded that the number of AgNORs in renal cell carcinoma was an additional factor for estimating the properties of tumor cells.

Key words: nucleolar organizer regions, AgNORs, renal cell carcinoma

要旨：1985年から1990年むでの 6 年間に千葉大学泌尿器科において腎摘出術を施行した腎細胞癌96例の AgNORs 数を計測し，これと病理学的所見や臨床経過との関係, 及び予後因子としての意義について検 討した. 銀コロイド染色方法は Ploton らの one-step 法に従い, AgNORs 数の算出法は Crocker らに準 じて出来る限りの AgNORsを計測した。

腎細胞癌の AgNORs 数は異型度が高くなるに従い増加した。細胞型との関係では通常型に比べ多形・ 紡鍾細胞型及びベリ二管癌においてその数が増加していた。 $\mathrm{pT}$ との関係では, 全異型度で $\mathrm{pT}_{1} ・ \mathrm{pT}_{2}$ と $\mathrm{pT}_{3 \mathrm{~b}}$ の間に差を認めたが，同一異型度内においては各 $\mathrm{pT}$ 間で差を認めなかった。静脈浸潤度との関係 でも, 全異型度で $\mathrm{pV}_{0}$ と $\mathrm{pV}_{1 \mathrm{a}}$ 及び $\mathrm{pV}_{1 \mathrm{~b}}$ との間で差を認めたが, 同一異型度内では各 $\mathrm{pV}$ 間で差を認めな かった。摘出腫瘍の最大長径と AgNORs 数は相関を示した. 原発巣, 肺転移栄, 後腹膜再発巣のいずれ かを画像上で経時的に観察出来た22例において腫瘍倍加時間を求め, 原発巣の AgNORs 数との関係を 検討した結果, 両者は逆相関を示した. 生存率は pT の進んだ例や高異型度例では低かったが, AgNORs では全症例でその数の多い群で生存率に低い傾向がみられたものの, 死亡数の多いG3症例ではその差を 認めなかった。以上より AgNORsは腎細胞癌において独立した予後因子といらょりはむしろ組織所見 や増殖速度に関連する補助的因子と考えられた。 
キーワード：核小体形成部位，AgNORs，腎細胞癌

\section{緒言}

核小体形成部位 (Nucleolar Organizer Regions: NORs）は，リボゾームRNAをコードするループ DNA の部位であり ${ }^{1)}$, そこに存在する RNA ポリメ ラーゼ12), C23タンパク, B23タンパク等34)の非ヒスト ン酸性タンパクは好銀性を有するため Argyrophilic Nucleolar Organizer Regions（AgNORs）と呼ばれ る. AgNORs は銀コロイド染色により光学顕微鏡で茶 褐色の斑状点として観察され5), 細胞あたりの AgNORs の数は, その細胞の増殖能を反映するといわ れる.したがって悪性腫瘍細胞では AgNORs 数の増 加が考学られ，実際悪性リンパ腫では悪性度に相関す $3^{6)}$ とか, 腎7), 皮膚 ${ }^{8)}$, 前立腺 ${ }^{9)}$, 乳腺 ${ }^{10)}$, 胸膜 ${ }^{11}$ 等で は良性腫瘍と悪性腫瘍の間で有意な差を認めたとの報 告がある。又乳癌では染色体 ploidy ${ }^{12)}$ や Ki-67 score $^{13) 14)}$ と, non-Hodgkin リンパ腫では S 期の細胞

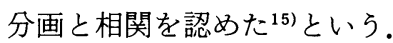

腎細胞癌の予後は個々の症例により多彩であり ${ }^{16)}$, 発育速度が広い範囲にわたっていることが推測され る. 今回予後と関連することとして挙げられている $\mathrm{pT}$, 異型度等の因子と AgNORs との関係及び予後因 子としての AgNORs の意義について検討した。

\section{対象および方法}

1985 年から1990年の 6 年間に千葉大学泌尿器科に拧 いて腎細胞癌の診断のもとに腎摘出術を行った96例を 対象とした。性別は男性68例, 女性28例, 年齢は28歳 から 82 歳 (平均61歳) であった。このうちの 41 例にお いては術前 3 日〜 7 日以内にコイルを用いて腎動脈塞 栓術を施行した。塞栓術施行症例は組織壊死，核变性 等の変化の見られない部分の AgNORsを計測した。

22例に扔いて原発巣, 後腹膜再発巣, 肺転移巣のい ずれかの画像を用いて腫瘍の倍加時間を算出し，それ と原発巣の AgNORs 数とを比較検討した。 その算出 法は, 腫瘍容積が棈円体であると仮定して以下の式よ り求めた。

$\mathrm{T}_{1}$ より $\mathrm{T}_{2}$ までの $\mathrm{T}$ 期間における腫瘍倍加時間 (D.T.)

$$
=\boldsymbol{\Delta} \mathrm{T} \cdot \log 2 \cdot\left(\log \mathrm{V}_{2}-\log \mathrm{V}_{1}\right)
$$

$\mathrm{V}$ : それぞれの時点での腫瘍容積

$\mathrm{pT}$ はUICC (1987年)の TNM 分類 ${ }^{17}$ に, その他の 組織学的分類は腎癌取扱い規約 ${ }^{18}$ に従った。異型度は ベリニ管癌を除く92例において判定したが，GX は 4
例であった，同一病変内に異なる異型度の存在する場 合には最も高異型度において計測し, その異型度のみ を表記した，異なる細胞型が存在する場合は量的に優 勢な細胞型において計測した。

AgNORs 観察のための銀コロイドの染色は, ホルマ リン固定パラフィン包埋標本について Ploton ら5の 方法に準じて行った，厚さ $3 \mu \mathrm{m}$ の切片を作製し，脱パ ラフィン後 $2 \%$ ラチン加 $1 \%$ 蟻酸溶液・硝酸銀混合 液（1：2）を暗室内で40分間反応させ，蒸留水にて 水洗し，アルコール，キシレンで脱水透徹後オイキッ トにて封入した. AgNORs 数は, 光学顕徽鏡を用いて 1,250倍で観察し，100個の細胞核内の AgNORs 数を 計測して， 1 細胞あたりの平均 $\mathrm{AgNORs}$ 数を表示し た. AgNORs の集合体に対しては，焦点の変更などに よって可能なものはその構成数を計測した.

各群の有意差検定にはStudents' $\mathrm{t}$ 検定を用いた。生 存率は癌死のみを死亡とし，他病死を追跡不能例とす る Cause-Specific Survival を手術日を起算日として Kaplan-Meier 法で計算した。生存率の検定には, log rank 法を用いた。

\section{結 果}

全ての腎細胞癌の細胞核内に AgNORsを認め, そ の数は平均 $7.7 \pm 2.4$ であった。しかしその形態は異型 度によって差があり，異型度の低いものでは比較的均 一なAgNORs が数個集まって集合体を形成する傾向 がみられたが，異型度が高くなるに従い大きさ形共に さまざまな AgNORs が集合体形成をする他に散在性 にも存在した（図 1a，b). 異型度別の AgNORs 数を みると，群内で広い範囲に数值が分散するため各群間 に重複がみられたものの，異型度の上昇に従って平均 AgNORs 数は増加した（図 2).

組織学的細胞型と AgNORs 数との関係は（表 1), 淡明細胞亜型と顆粒細胞亜型との間では差を認めな かったが，これらに混合亜型を含めた通常型と多形・ 紡鍾細胞型及びベリ二管癌との間では AgNORs 数に 差を認め, 通常型以外の型にその数が多かった.

原発巣の $\mathrm{T}$ 分類では対象症例のらち $\mathrm{pT}_{1}$ が 1 例の みのため, $\mathrm{pT}_{2}$ と一括して検討した（表 2 )。全異型度 では pT が進行するにつれて AgNORs 数の増加がみ られたが，同一異型度内では $\mathrm{pT}$ との関連はみられな かった。しかし同一 $\mathrm{pT}$ 内では異型度の上昇に従って AgNORs 数は増加した。 
図 1 腎細胞癌組織の銀コロイド染色 a : Grade 1, b : Grade 3

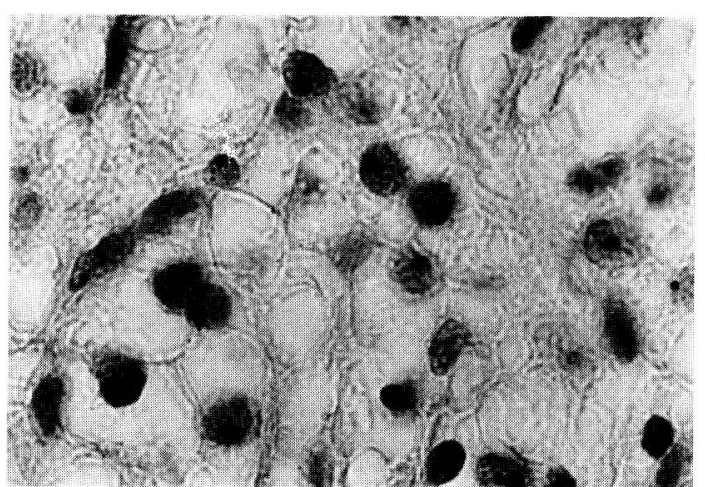

a

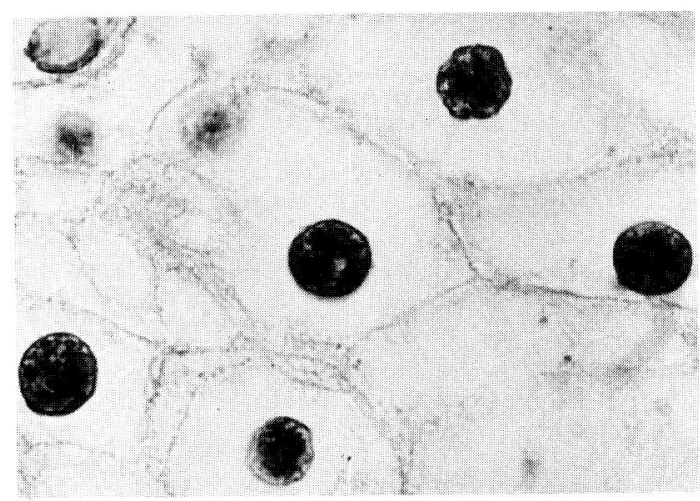

b

図 2 異型度と AgNORs

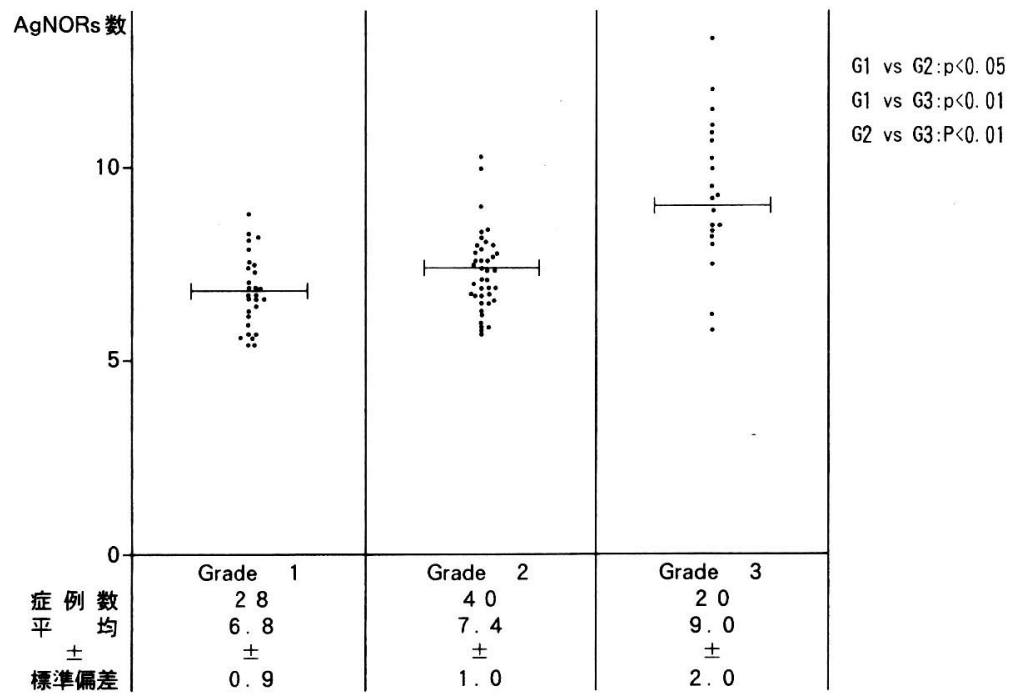

表 1 組織学的細胞型と AgNORs

\begin{tabular}{|c|c|c|}
\hline 組織学的細胞型 & 症例数 & $\begin{array}{l}\text { AgNORs 数 } \\
\text { (mean } \pm \text { SD) }\end{array}$ \\
\hline 通 常 型 & 86 & $7.5 \pm 1.5$ \\
\hline 淡明細胞垔 型 & 72 & $7.4 \pm 1.4$ \\
\hline 顆 粒 細 胞亜型 & 10 & $7.3 \pm 1.2$ \\
\hline 混合細胞亜 型 & 4 & $8.0 \pm 2.1$ \\
\hline 紡錘・多形細胞型 ${ }^{*}$ & 6 & $10.0 \pm 2.2$ \\
\hline ベリ二管癌 & 4 & $9.7 \pm 2.3$ \\
\hline & & $\begin{array}{l}*: p<0.01 \\
*: p<0.01\end{array}$ \\
\hline
\end{tabular}

表 2 pT とAgNORs

\begin{tabular}{|c|c|c|c|c|}
\hline & & & & ）：应例娄 \\
\hline & G 1 & G 2 & G & 全異型度 \\
\hline$p T_{1} \cdot p T_{2}$ & $6.8 \pm 0.9^{a}$ & $7.2 \pm 1.1^{b)}$ & $12.2 \pm 1.5^{\mathrm{a}) \mathrm{b}}$ & $7.2 \pm 1.5^{*}$ \\
\hline & (22) & (17) & (2) & (41) \\
\hline $\mathrm{pT}_{30}$ & $6.8 \pm 1.0^{c)}$ & $7.6 \pm 1.0$ & $8.1 \pm 1.2^{c)}$ & $7.7 \pm 1.3$ \\
\hline & (4) & (18) & (9) & (31) \\
\hline $\mathrm{pT}_{30}$ & $7.8 \pm 1.0$ & $6.9 \pm 0.9$ d) & $9.2 \pm 2.1^{d)}$ & $8.3 \pm 2.3^{*}$ \\
\hline & (2) & (5) & (8) & (15) \\
\hline $\mathrm{pT}_{4}$ & - & - & 8.2 & 8.2 \\
\hline & & & (1) & (1) \\
\hline
\end{tabular}

a) b) d): $: p<0.010$ c) : $p<0.05$ 
静脈浸潤度別にAgNORs 数を検討した（表 3 ）。全 異型度では静脈浸潤が拡大するにつれて AgNORs 数 の増加がみられたが, 同一異型度内では静脈浸潤度と の関連は見られなかった。しかし静脈浸潤度が同一の 場合には異型度の上昇に従って AgNORs 数に増加の 傾向がみられた。

リンパ節転移の有無とAgNORs 数の関係を検討し た（表 4 ）. 全異型度及び G3において $\mathrm{pN}(+)$ が $\mathrm{pN}$ (一)に比べAgNORs 数が多い傾向がみられた。また, リンパ節転移の有無にかかわらず異型度の上昇にした
表 3 静脈浸潤度と AgNORs

\begin{tabular}{|c|c|c|c|c|}
\hline & & & & ）：在制数 \\
\hline & G 1 & G 2 & G 3 & 全臬型度 \\
\hline $\mathrm{pV}$ 。 & $\begin{array}{c}6.7 \pm 0.9^{\mathrm{a})} \\
(24)\end{array}$ & $\begin{array}{c}7.3 \pm 0.6^{\mathrm{a})} \\
(14)\end{array}$ & $\begin{array}{r}10.2 \pm 2.7 \\
\text { (3) }\end{array}$ & $\begin{array}{r}7.1 \pm 1.7^{*} \\
(41)\end{array}$ \\
\hline$p V_{10}$ & $\begin{array}{r}7.1 \pm 0.7 \\
\text { (2) }\end{array}$ & $\begin{array}{r}7.5 \pm 1.1 \\
(20)\end{array}$ & $\begin{array}{r}8.3 \pm 1.7 \\
(8)\end{array}$ & $\begin{array}{r}7.7 \pm 1.4 \\
(30)\end{array}$ \\
\hline $\mathrm{pV}_{10}$ & $\begin{array}{r}7.8 \pm 0.9 \\
(2)\end{array}$ & $\begin{array}{r}7.9 \pm 2.1 \\
\text { (3) }\end{array}$ & $\begin{array}{r}8.6 \pm 1.4 \\
\text { (3) }\end{array}$ & $\begin{array}{c}8.2 \pm 2.0^{*} \\
(8)\end{array}$ \\
\hline $\mathrm{pV}_{2}$ & - & $\begin{array}{c}6.3 \pm 0.7^{b)} \\
(3)\end{array}$ & $\begin{array}{c}9.4 \pm 2.3^{b)} \\
(6)\end{array}$ & $\begin{array}{r}8.4 \pm 2.8 \\
(9)\end{array}$ \\
\hline
\end{tabular}

表 4 リンパ節転移と AgNORs

\begin{tabular}{|c|c|c|c|c|}
\hline & & & & ）：应例数 \\
\hline & G 1 & G 2 & G 3 & 全 暴型 度 \\
\hline $\mathrm{pN}(-)$ & $\begin{array}{c}\left.6.6 \pm 0.9^{a) b}\right) \\
(20)\end{array}$ & $\begin{array}{c}\left.7.5 \pm 1.0^{a) c}\right) \\
(29)\end{array}$ & $\begin{array}{c}\left.8.8 \pm 1.8^{* b) c}\right) \\
(14)\end{array}$ & $\begin{array}{c}7.5 \pm 1.7^{\hat{H}} \\
(63)\end{array}$ \\
\hline $\mathrm{pN}(+)$ & - & $\begin{array}{c}7.2 \pm 1.6^{d)} \\
(3)\end{array}$ & $\begin{array}{c}10.8 \pm 1.3^{* d)} \\
(3)\end{array}$ & $\begin{array}{c}9.0 \pm 2.4^{4} \\
(6)\end{array}$ \\
\hline
\end{tabular}

a) b): $p<0.01$

c): $p<0.05$

d) : $p<0.10$

図 3 最大腫瘍長径と AgNORs

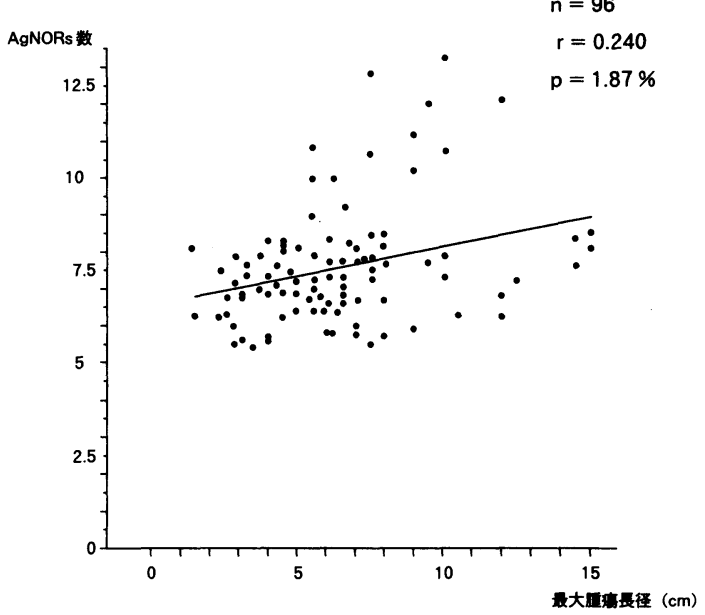

図 4 腫瘍倍加時間とAgNORs

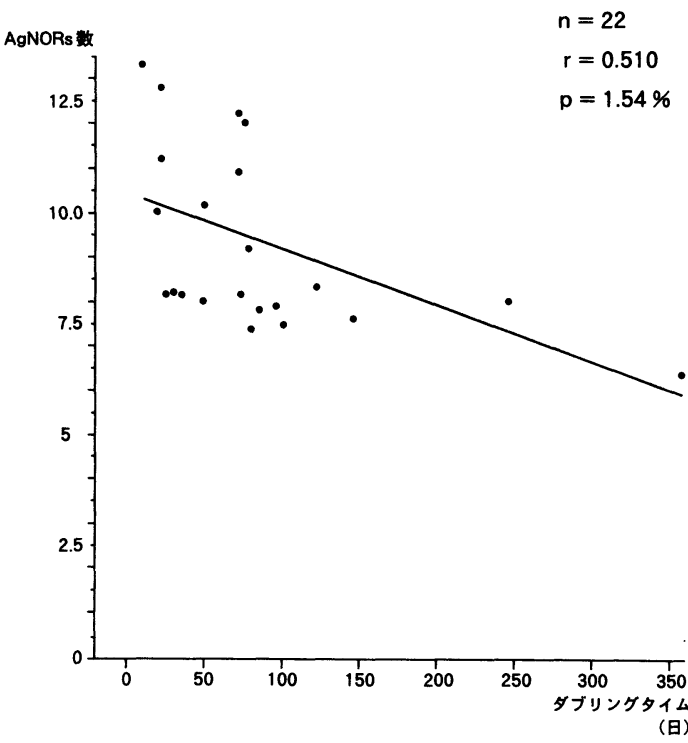

$\mathrm{AgNORs}$ 数との関連をみると,両者は逆相関を示した (図 4 )。

対象とした96例の観察期間は29日〜2,036日（平均 741日)であり, この間癌なし生存72例, 坦癌生存 5 例,

腫瘍倍加時間を計算できた22例について, 原発巣 
図 5 pT と生存率

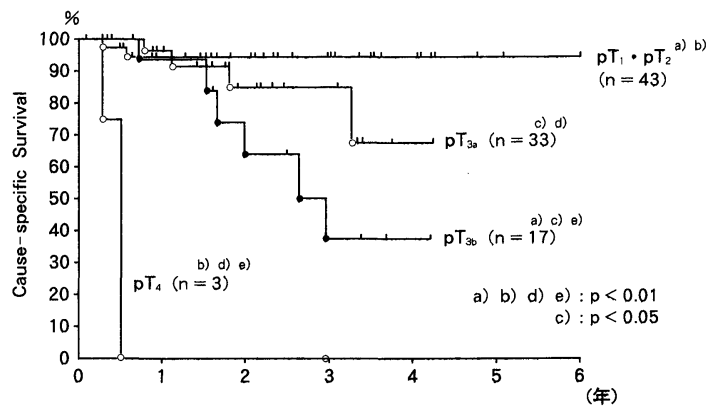

図 6 異型度と生存率

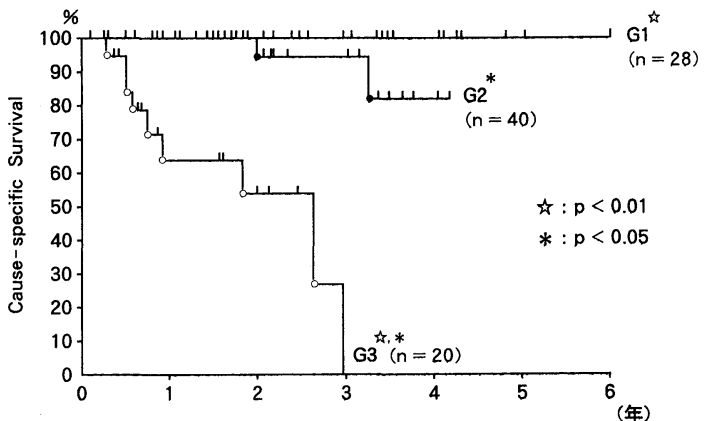

図 7 AgNORs と生存率

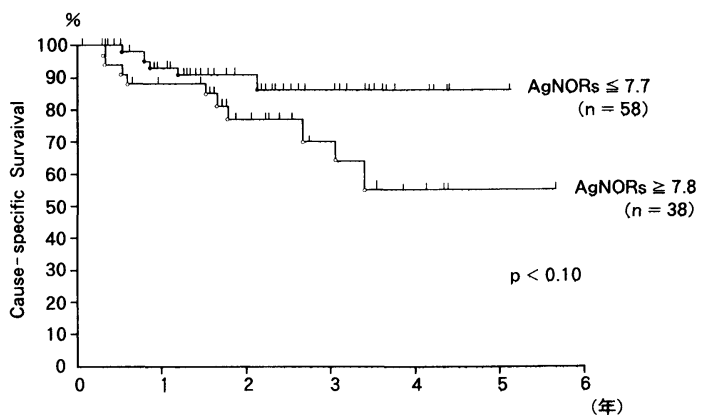

癌死19例であった，その術後生存率を病期別にみた結 果, pTの進行に従って生存率は低下した（図 5 )。 。 た術後生存率と異型度との関係についても，異型度が 高くなるに従って生存率は低下した(図6)，腎細胞癌 の AgNORs 数の平均值7.7に拈いて 2 分化し, 生存率 を検討した結果, AgNORs 数の多い群に生存率の低い 傾向がみられた（図 7 )。G1，G2症例では死亡数が 2 例と少ないため死亡数の多いG3症例において，その AgNORs 数の平均値9.0で 2 分化し生存率を検討した 結果，両群で差は見られなかった（図 8 ).
図 8 G3 症例における AgNORs と生存率

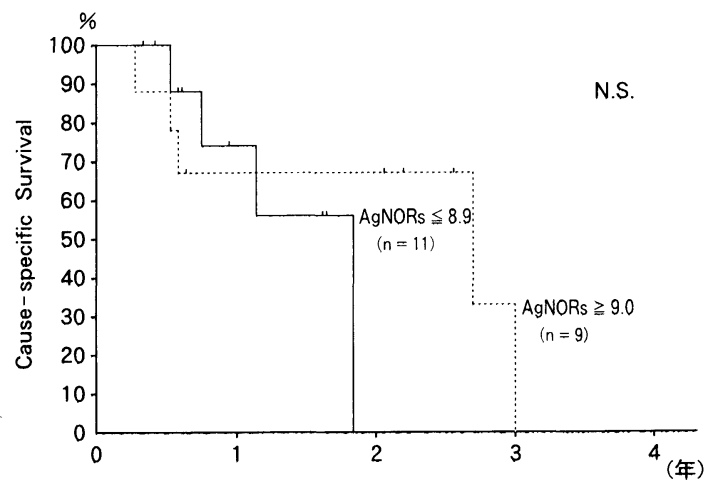

考察

銀コロイドを用いた核小体形成部位の染色方法は

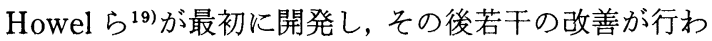
れた . 諸家の報告の AgNORs 染色もこれに従ってい るものが多いが, その反応時間は様々である. Mourad $ら^{20)}$ は小児 Wilms 腫瘍に対して反応時間を45分とし ており，またDelhuntら ${ }^{21)}$ は腎細胞癌組織にたいして 30分から35分としている。一方 Pich ら ${ }^{22)}$ は95\%エタ ノール固定の腎細胞癌を 8 分から10分の反応時間で観 察していることより，反応時間は固定法，固定時間， 摘出標本の大きさ等により最適な時間を選択する必要 があると思われる、今回の検討では反応時間を 40 分と し，良好な観察状態を得た。

AgNORs は核内に茶褐色の顆粒として認められる が，それらは時に集合体を形成する。集合体について は，構成する顆粒を別個に計測するか集合体全体を 1 つと計測するかに分けられる2324). 両者の算出法は黒

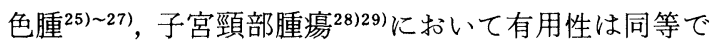
あるとされており，後者は前者に比べ計測の簡便さ及 び再現性に扣いて優れているといら ${ }^{24)}$. しかし核内に 打けるAgNORsの形態と分布に関しては，大腸で良 性腫瘍は集合体形成の傾向が強く，悪性腫瘍は集合体 形成はあまり認められないといら30131)一方，皮膚の黒 色腫 ${ }^{32)}$ や胃の筋原性腫瘍 ${ }^{33)}$ では良性病変に扎いて集合 体形成はあまりみられず，悪性病変において集合体形 成がみられたといら、腎細胞癌では Pich ら 22) も今回の 検討と同様に異型度の低い病変で均一な AgNORs が 集合体を形成する傾向が見られたが，異型度が高くな るに従い集合体形成の他に散在性に大小様々な AgNORs が多数見られたと報告している.このように 集合体に対する評価はまちまちであり，また集合体の 中には数個の AgNORs が識別できるものが多数あっ 
たため，今回は集合体を構成する顆粒についておのお のを計測した。

腎細胞癌は早期に遠隔転移を来し予後不良な経過を たどる例, あるいは術後 10 年以上を経て転移再発を来 しその後も緩徐な経過をたどる例など多彩な経過を示 す16). 本邦に怙ける腎細胞癌の予後に関しては 5 年生 存率 $45 \%$ ～60.0\%，10年生存率 $34 \%$ ～53.7\%などと報 告されており, その予後因子としては, 異型度, $\mathrm{pT}$, 病期, 組織学的細胞型, 腫瘍塞栓, リンパ節転移, 遠 隔転移, 腫瘍長径などが挙げられている34) 38). しかし いずれも単独の因子としては十分に予後を予測できる ものとはい方ず，今回の検討では死亡例のなかった Grade 1症例でもリンパ節転移, 遠隔転移, あるいは腫 瘍の大きさなどが予後に影響を及ぼす39)という。あた これらの因子のらちどれが最も予後に寄与するもので あるかは現在議論のあるところである。腎細胞癌にお ける今回の検討ではこれらの因子と AgNORs 数はい ずれも相関をみた。しかし $\mathrm{pT}$, 静脈浸潤度では全異型 度の平均で AgNORs との相関を認めたが, 同一異型 度内ではそれらとAgNORs 数に関係を認めなかっ た. 異型度と AgNORs 数は相関しており,また pTや 静脈浸潤度を揃えた場合に異型度の上昇に従って AgNORs 数が増加していたことより, pT 及び静脈浸 潤度と AgNORs 数との相関は異型度に依存している 可能性が考えられた。膀胱腫瘍401の組織異型度と脈管 浸潤の間に打いても同様な報告があることより，

AgNORs 数と病期, 臨床所見等との比較検討に招いて は核異型度, 組織異型度の分布を考慮する必要がある と思われた。

今回の検討にて原発巣, 肺転移巣もしくは後腹膜再 発巣より得られた腫瘍倍加時間之原発巣 AgNORs 数 とは逆相関を示した。神経芽腫の培養細胞において倍 加時間とAgNORs 数が相関したとのこと融である が, 臨床的に得られた倍加時間と AgNORs 数が相関 したとの報告はまだない、今回は, 原発巣の AgNORs 数と転移, 再発巣を含めた腫瘍倍加時間とを比較して いるため厳密なものとは言い難いが，草間は原発巣と 転移巣の倍加時間は相関している可能性がある ${ }^{42)} と し$ て打り, 又胃癌 ${ }^{43)}$, 副甲状腺癌 44 )では原発巣とリンパ節 転移巣に打いて AgNORs 数に差を認めなかったとい 5. 胃癌において腫瘍倍加時間は予後因子である ${ }^{44)}$ とより腎細胞癌の AgNORs 数は, 転移再発症例の経 過を予見するうえで有用であろう。

腎細胞癌の生存率との関連では, AgNORs 数は独立
した予後因子であるといら211. 今回の検討では AgNORs 数は従来より予後因子であるという異型度, 組織学的細胞型, pT, 静脈浸潤度, 腫瘍長径等々相関 を認めた。しかしこれらのらち pT, 静脈浸潤度では同 一異型度内で検討した場合に相関を認めなかったが, 異型度とは同一の病期内及びリンパ節転移の有無にか かわらず相関を認めた。術後累積生存率の検討では, 異型度と $\mathrm{pT}$ で生存率に差を認め, AgNORs 数でもそ の数の多い症例で生存率の低い傾向がみられた。しか し死亡数の多いG3症例に限ると AgNORs 数の大小 で差が認められなかったことより腎細胞癌に怙ける AgNORs 数は独立した予後因子といらよりはむしろ 異型度に相関し，その増殖速度を反映する因子ではな いかと考えられた。

\section{結 語}

腎細胞癌の銀コロイド染色に扮いて以下の結論を得 た。

1. AgNORs 数は, 異型度, 組織学的細胞型, 病期, 静脈浸潤度で差を認め, 畽瘍長径と相関した。しかし 病期, 静脈浸潤度では同一異型度内では差がなかった。

2. 腫瘍倍加時間と原発巣 AgNORs 数は逆相関を 示した。

3. AgNORs 数の大小で生存率に差のある傾向で あったが, 死亡数の多いG3症例ではその差を認めな かった。

4. 以上より AgNORs は異型度や増殖速度と関連 しているが，数値が広い範囲に分布して打り独立した 予後因子といらょりむしろ組織学的所見に関連する因 子と考光られた。

\section{文献}

1) Rüschof, J., Plate, A., Bittinger, A. and Thomas, C.: Nucleolar organizer regions (NORs), basic concept and practical application in tumor pathology. Path. Res. Pract., 185, 878-885, 1989.

2) Marilyn, A.W., Jurgen, A.K., Georg, K. and Werner, W.F.: Argyrophilic nuclear and nucleolar patterns of Xenophus leavis oocytes identified by gel ectrophoresis. Exp. Cell Res., 137, 341-351, 1982.

3) Michael, A.L., Karel, S., Mark, O.J.O. and Harris, B.: Proteins $\mathrm{C} 23$ and B23 are the major silver staining proteins. Life Sci., 25 , 701-708, 1979.

4) Robert, L.O. and Harris, B.: Further evidence that phosphoproteins $\mathrm{C} 23(110 \mathrm{KD} / \mathrm{pH} 5.1)$ is the 
nucleolar silver staining protein. Exp. Cell Res., 152, 260-265, 1984.

5) Ploton, D., Menager, M., Jeannesson, P., Himber, G., Pigeon, F., Adnett, J.J. : Improvement in the staining and in the visualizatin of the Argyrophilic proteins of the nucleolar organizer regions at the optical level. Histochem. J., 18, 5-14, 1986.

6) Crocker, J. and Nar, P.: Nucleolar organizer regions in lymphomas. J. Pathol., 151, 111-118, 1987.

7) Bryan, R.L., Crocker, J. and Farr, A.: Nucleolar oranizer regions in kidney tumours and xanthoganulomatous pyelonephritis. J. Clin. Pathol., 43, 147-148, 1990.

8) Crocker, J. and Skilbeck, N. : Nucleolar organizer region associated proteins in cutaneous legions: A quantitative study. J. Clin. Pathol., 40, 885-889, 1987.

9) Masai, M., Abe, K., Akimoto, S., Yatani, R. and Shimazaki, J.: Argyrophilic nucleolar organizer regions in benign hyperplastic and cancerous human prostates. Prostate, 20, 1-13, 1992.

10) Smith, R. and Crocker, J.: Evaluation of nucleolar organizer region-associated proteins in breast malignancy. Histopathology, 12, 113-125, 1988.

11) Ayres, J., Crocker, J. and Skilbeck, N. : Differentiated of malignancy from normal and reactive mesothelial cells by the argyrophil technique for nucleolar organizer region associated proteins. Thorax, 43, 366-370, 1988.

12) Giri, D.D., Nottingham, J.F., Lawry, J., Dundas, S.A. and Underwood, J.C.E.: Silver-binding nucleolar organizer regions (AgNORs) in benign and malignant breast lesions: Correlations with ploidy and growth phase by DNA flow cytometry. J. Pathol., 157, 307-313, 1989.

13) Dervan, P.A., Gilmartin, L.G., Loftus, B.M. and Carney, D.N.: Argyrophilic nucleolar organizer region counts correlate with Ki67 scores. Am. J. Clin. Pathol., 92, 401-407, 1989.

14) Wendy, A.R. and Anthony, S.-Y.L.: Nucleolar organizer regions relate to growth fractions in human breast carcinoma. Hum. Pathol., 20, 741-746, 1989.

15) Crocker, J., Macartney, J.C. and Smith, P.J. : Correlation between DNA flow cytometric and nucleolar organizer region data in nonHodgkin's lymphomas. J. Pathol., 154, $151-156,1988$.

16）里見佳昭：腎癌の最近の治療と予後. 病理と臨床,
8, 726-731, 1990.

17) UICC. International Union Against Cancer : Urological tumors. in: Hermanek, P. and Sobin, L.H., "TNM Classification of Malignant Tumors” 4th ed. Berlin : Springer-Verlag, 1987, p. $121-144$.

18）日本泌尿器科学会, 他編：腎癌取り扱い規約, 第 1 編, 金原出版, 東京, 1983.

19) Howell, W.M. and Black, D.A.: Controlled silver staining of nucleolus organizer regions with a protective colloidal developer: A onestep method. Experientia, 36, 1014, 1980.

20) Mourad, W.A., Lavallee-Grey, M., Pappenhausen, P., Essig, Y.P. and Rowlands, D.T. Jr. : Argyrophilic nucleolar organizer regins in Wilm's tumours and related legions: A histologic and chromozomal correlation. J. Article, 4, 247-252, 1991.

21) Delahunt, B., Ribas, J.L., Nacey, J.N. and Bethwaite, P.B.; Nucleolar organizer regions and prognosis in renal cell carcinoma. J. Pathol., 163, 31-37, 1991.

22) Pich, A., Valente, G., Azzoni, L., Stramignoni, A., Margaria, E. and Tasso, M. : Argyrophilic nucleolar organizer region counts and $\mathrm{Ki}-67$ scores in human renal cell carcinoma. Path. Res. Pract., 187, 482-486, 1991.

23) Crocker, J., Boldy, D.A.R. and Egan, M.J. : How should we count AgNORs? Proposals for a standardized approach. J. Pathol., 158, 185-188, 1989.

24) Howat, A.J., Giri, D.D., Wright, A.L. and Underwood, J.C.E. ; Silver-stained nucleoli and nucleolar organizer region counts are of no prognostic value in thick cutaneous malignant melanoma. J. Pathol., 156, 227-232, 1988.

25) Leong, A.S-Y. and Gilham, P.: Silver staning of nucleolar organizer regins in malignant melanoma and melanotic nevi. Human Pathol., 20, 257-262, 1989.

26) Howat, A.J., Giri, D.D., Cotton, D.W.K. and Slater, D.N. : Nucleolar oranizer regions in Spitz nevi and malignant melanomas. Cancer, 63, 474-478, 1989.

27) Howat, A.J., Wright, A.L., Cotton, D.W.K., Reeve, S. and Bleehen, S.S.: AgNORs in benign, dysplastic and malignant melanocytic skin legions. Am. J. Dermatopathol., 12, 156-161, 1990.

28) Thickett, K.M., Griffin, N.R., Griffin, A.P. and Wells, M. : A study of nucleolar organizer regions in cervical intraepithelial neoplasia and 
human papillomavirus infection. Int. J. Gynecol. Pathol., 8, 331-339, 1989.

29) Cullimore, J.E., Rollason, T.P., Marshall, T. : Nucleolar organizer regions in adenocarcinoma in situ of the endocervix. J. Clin. pathol., 8, 1276-1280, 1989.

30) Yang, P., Huang, G.S. and Zhu, X.S.: Role of nucleolar organizer regions in differenticating malignant from benign tumors of the colon. J. Clin. Patol., 43, 235-238, 1990.

31) Derenzini, M., Romagnoli, T., Mingazzini, P. and Marinozzi, V.: Interphasic nuclelar organizer region distribution as diagnostic parameter to differentiate benign from malignant epithelial tumors of human intestine. Virchows Arch. [B], 54, 334-340, 1988.

32) Fallowfield, M.E. and Cook, M.G.: The value of nucleolar organizer regin staining in the differential diagnosis of borderline melanocytic legions. Histopathol., 14, 299-304, 1989.

33) Sinn, H.P., Lehnert, T., Kandetzki, C. and Waldherr, R.: Nucleolar orgaizer in regions in myogenic stromal tumours of the stomach. Virchows Arch. [A], 415, 317-321, 1989.

34）佐藤 健, 川合弘二, 西島由貴子, 佐々木明, 桐山 功, 吉井慎一, 宮永直人, 岩崎明朗, 阿弥良浩, 真 鍋文雄, 石川博通, 小磯謙吉：腎細胞癌の臨床的研 究一新しいTNM 分類に基づいた予後の検討一. 日泌尿会誌，80，1802-1808，1989.

35）中西正一郎, 柏木 明, 坂下茂夫, 丸 彰夫, 小柳 知彦, 有門克彦, 森 達也, 川倉宏一, 大橋伸生, 山田智二, 期波光生：腎細胞癌の病理組織学的検 討一核型に上る悪性度と予後について一。 日泌尿 会誌, 75, 1637-1645, 1984.

36）里見佳昭, 福田百邦, 穂坂正彦, 近藤猪一朗, 吉邑 貞夫, 福島修司, 井田時雄, 広川 作, 森田 上, 古畑哲彦, 熊谷治巳, 塩崎 洋, 石塚栄一, 宮井啓
国, 仙賀 裕, 福岡 洋, 佐々木紘一, 公元昭男, 中橋 満: 腎癌の予後に関する臨床統計. 日泌尿 会誌, 79, 853-863， 1988.

37）高士宗久, 坂田孝雄, 中野洋二朗, 長井辰哉, 高羽 秀典, 田中純二, 岡村菊夫, 高村真一, 金井 茂, 佐橋正文, 村瀬達良, 下地俊雄, 三宅弘治: 腎細胞 癌の臨床病理学的特徵々予後. 日泌尿会誌, 83, 321-327, 1992.

38）畺田嘉彦：腎細胞癌の予後. 日泌尿会誌, 72, $10-25,1981$.

39）五十嵐辰男, 村上信乃, 富岡 進, 阿部功一, 井坂 茂夫, 岡野達弥, 正井基之, 島崎 淳, 松㟢 理 : Gradel 腎癌の予後. 日泌尿会誌，80，264-269, 1989.

40）竹内敏視：膀腅腫瘍に打ける核小体形成体の研 究. 日泌尿会誌，81，1711-1719，1990.

41) Trerè, D., Pession, A. and Derenzini, M. : The silver-stained proteins of interphasic nucleolar organizer regions as a parameter of cell duplicaton rate. Experimental Cell Research, 184, 131-137, 1989.

42）草間 悟: 再発癌. SLR 宝函, 10, 1-7, 1986.

43) Kakeji, Y., Korenaga, D., Tsujitani, S., Haraguchi, M., Maehara, Y. and Sugimachi, K. ; Predictive value of Ki67 and argyrophilic nucleolar organizer region staining for lymph node metastasis in gastric cancer. Cancer Research, 51, 3503-3506, 1991.

44) Bouquist, L.L.: Nucleolar organizer regions in normal, hyperplastic and neoplstic parathyroid glands. Virchows Arch [A], 417, 237-241, 1986.

45）高橋 豊, 磨伊正義, 草間 悟：癌患者の予後規定 因子としての発育速度. Oncologia, 16, 141-143, 1986.

（1993年 1 月11日受理，特別掲載） 